\title{
Efek suplementasi tepung kulit jengkol pada pelepah sawit fermentasi terhadap profil mikroba rumen dan produksi gas metan in vitro
}

\author{
Nurhaita ${ }^{1}$, Nur Hidayah ${ }^{2, *}$, Neli Definiati ${ }^{1}$ \\ 1Program Studi Peternakan, Fakultas Pertanian, Universitas Muhammadiyah Bengkulu, Bengkulu, 38119 \\ 2Program Studi Peternakan, Fakultas Pertanian, Universitas Tidar, Magelang, 56116 \\ *Correspondence: nurhidayah@untidar.ac.id; Telp.: +62-812-9711-4749
}

Received: June $1^{\text {th }}, 2020$; Accepted: January 19 ${ }^{\text {th }}, 2021$; Published online: March $18^{\text {th }}, 2021$

\begin{abstract}
Abstrak
Tujuan: Penelitian ini bertujuan untuk mengevaluasi efek suplementasi tepung kulit jengkol pada pelepah sawit fermentasi terhadap profil mikroba rumen dan produksi gas metan secara in vitro.

Metode: Rancangan yang digunakan pada penelitian in vitro adalah rancangan acak kelompok dengan 4 perlakuan (pelepah sawit fermentasi dengan suplementasi tepung kulit jengkol pada level $0,2,4$, dan $6 \%$ ) dengan 4 kelompok sebagai ulangan. Peubah yang diamati yaitu profil mikroba rumen (populasi bakteri total, selulolitik, dan protozoa), produksi gas metan, proporsi volatile fatty acid (VFA) parsial dan rasio asetat / propionat (A/P). Data yang diperoleh dianalisa secara statistik menggunakan analisis of varian (ANOVA), perbedaan nyata antar perlakuan diuji lanjut dengan uji Duncan Multi Range Test (DMRT).

Hasil: Hasil penelitian menunjukkan bahwa suplementasi kulit jengkol sebanyak $6 \%$ dari pakan meningkatkan $(\mathrm{P}<0,05)$ populasi bakteri total dan bakteri selulotik. Suplementasi kulit jengkol sebanyak 4 dan $6 \%$ menurunkan $(\mathrm{P}<0,05)$ populasi protozoa, produksi metan, proporsi asetat dan rasio A/P. Suplementasi kulit jengkol sebanyak $2 \%$ meningkatkan $(\mathrm{P}<0,05)$ proporsi propionate.

Kesimpulan: Kesimpulannya, pelepah sawit fermentasi dapat disuplementasi dengan tepung kulit jengkol sebanyak $2 \%$ dari pakan yang efeknya tidak mengganggu profil mikroba rumen, mampu menurunkan produksi gas metan, proporsi asetat dan rasio $\mathrm{A} / \mathrm{P}$ serta meningkatkan proporsi propionat.
\end{abstract}

Kata Kunci: Profil mikroba; Produksi metan; Pelepah sawit fermentasi; Tepung kulit jengkol

Abstract

Objective: This research was aimed to evaluation the effect of supplementation jengkol peel powder in fermented oil palm fronds on rumen microbes profile and methane production on in vitro.

Methods: The used design was factorial randomized block design with four treatments supplementation of jengkol peel powder at $0,2,4$, and $6 \%$ and four groups as replications. The observed variables were rumen microbes profile (population of total bacteria, cellulolytic, and protozoa), methane production, partial volatile fatty acid (VFA) proportion and acetate/propionate $(\mathrm{A} / \mathrm{P})$ ratio. The data were analyzed using ANOVA and different among treatments means examined by Duncan Multiple Range Test (DMRT). 
Results: The result showed that supplementation of jengkol peel powder at $6 \%$ substrate increased $(\mathrm{P}<0.05)$ total and cellulolytic bacteria population. Jengkol peel powder supplementation as much as 4 and $6 \%$ decreased $(\mathrm{P}<0.05)$ protozoa population, methane production, acetate proportion and $\mathrm{A} / \mathrm{P}$ ratio. Supplementation of jengkol peel powder at $2 \%$ increased $(\mathrm{P}<0.05)$ propionate production.

Conclusions: In conclusion, fermented oil palm fronds can be substituted with jengkol peel powder at $2 \%$ substrate that did not disturb rumen microbes profile, decreased methane production, acetate proportion, $\mathrm{A} / \mathrm{P}$ ratio and increased propionate production on in vitro.

Keywords: Rumen microbes profile; Methane production; Fermented oil palm fronds; Jengkol peel powder

\section{PENDAHULUAN}

Prinsip untuk meningkatkan efisiensi pakan pada ternak ruminansia yaitu meminimalkan hilangnya energi dengan cara meningkatkan kecernaan pakan dan manipulasi fermentasi rumen, Khiaosa and Zebeli [1]. Beauchemin and McGinn [2] melaporkan bahwa produksi gas metan menggambarkan hilangnya energi bruto pakan sebanyak $2-12 \%$ atau 6-10\%, Jayanegara [3]. Penelitian terkait suplementasi senyawa bioaktif tanaman pada pakan ternak sudah banyak terbukti mampu memperbaiki profil mikroba rumen sehingga berdampak positif terhadap peningkatan produktifitas ternak. Hasil meta analisis in vitro Klevenhusen et al. [4] dan in vivo Khiaosa and Zebeli [1] melaporkan bahwa suplementasi senyawa bioaktif dapat digunakan sebagai agen modifikasi mikroba rumen dan penurun produksi gas metan.

Kulit jengkol merupakan salah satu byproduk tanaman pangan yang tidak termanfaatkan dan hanya menjadi sampah sehingga dapat mencemari lingkungan. Hidayah et al. [5] melaporkan bahwa kulit jengkol baik dari segi kuantitas dan kualitasnya berpotensi digunakan sebagai bahan supementasi pakan ternak. Proporsi kulit jengkol sebesar 59,99\%, sedangkan proporsi bijinya hanya sebesar $40,01 \%$. Kulit jengkol berpotensi digunakan sebagai sumber saponin (17,91-35,13\%) dan mengandung beberapa senyawa bioaktif lainya yaitu tannin, total fenol, dan flavonoid. Saponin merupakan agen defaunasi protozoa yang mampu membunuh atau melisiskan protozoa rumen, Hart et al. [6]. Penurunan populasi protozoa ini akan diikuti dengan penurunan produksi gas metan. Aktivitas senyawa bioaktif yang bersifat anti protozoa bertanggung jawab terhadap terhambatnya produksi gas metan di dalam rumen, Soliva et al. [7].

Pelepah sawit merupakan limbah dari perkebunan sawit yang sangat berpotensi digunakan sebagai alternatif sumber hijauan pakan ternak. Ketersediaanya melimpah, namun belum dimanfaatkan secara optimal, sebagian besar pelepah sawit masih menjadi limbah karena hanya dibuang atau ditumpuk dibawah batang sawit. Nurhaita et al. [8] melaporkan bahwa pelepah sawit merupakan pakan limbah yang kualitas dan nilai gizinya rendah, fraksi seratnya tinggi, serta palatabilitas dan kecernaannya rendah. Berdasarkan hasil penelitian Nurhayu et al. [9], pelepah sawit mengandung serat kasar yang tinggi (50.94\%) dan protein kasar yang sangat rendah $(3,07 \%)$. Chaves et al. [10] menyatakan bahwa kualitas pakan berpengaruh terhadap produksi gas metan $\left(\mathrm{CH}_{4}\right)$ pada kajian in vitro dimana rendahnya konsentrasi karbohidrat yang tidak berserat pada legume dan hijauan berkontribusi terhadap tingginya produksi gas metan per gram bahan kering yang dikonsumsi.

Rendahnya nilai gizi dan nilai kecernaan dari pelepah sawit dapat ditingkatkan dengan teknologi pengolahan fermentasi. Produk fermentasi memiliki kualitas gizi dan kecernaan yang lebih baik dibanding produk asal yang tanpa fermentasi, Astuti et al. [11]. Suplementasi senyawa bioaktif pada pelepah sawit fermentasi dirasa sangat perlu sebagai upaya meningkatkan kualitas limbah pelepah sawit dengan tujuan untuk modifikasi mikroba rumen. Modifikasi mikroba rumen diharapkan mampu meningkatkan populasi bakteri rumen, menurunkan protozoa dan produksi gas metan sehingga efisiensi 
pakan dan produktivitas ternak meningkat. Penelitian ini bertujuan untuk mengevaluasi suplementasi tepung kulit jengkol pada pelepah sawit fermentasi terhadap profil mikroba rumen dan produksi gas metan secara in vitro.

\section{MATERI DAN METODE}

\section{Pembuatan tepung kulit jengkol}

Kulit jengkol dikumpulkan, dibersihkan, dikeringkan matahari sampai mencapai berat kering yang stabil, dan digiling sampai berbentuk tepung.

\section{Pembuatan mikrooragnisme lokal (MOL)}

MOL yang dibuat berdasarkan metode Nurhaita et al. [8]. Sumber mikroorganisme diambil dari isi rumen kambing (2 kg) sedangkan sumber energinya dari air kelapa $(15 \mathrm{~L})$ dan molasses $(4 \mathrm{~kg})$. Bahan-bahan tersebut dimasukkan ke dalam jerigen, ditutup rapat dan diaduk rata dengan cara diguncangkan. Kemudian disiapkan jirigen lain yang ukurannya lebih kecil untuk diisi air dan ditutup rapat. Kedua tutup jirigen tersebut dilubangi dan dihubungkan dengan selang kecil pada kedua tutup jirigen tersebut. Jirigen kecil yang berisi air berfungsi menampung gas yang terbentuk selama 10 hari inkubasi dalam pembuatan MOL.

\section{Fermentasi pelepah sawit}

Pencacahan dengan menggunakan chopper sebanyak 3 kali dilakukan pada pelepah sawit. Penjemuran matahari sampai didapatkan kadar air sebesar $\pm 60 \%$. Pelepah sawit yang sudah kering ditambahkan MOL $10 \mathrm{ml} / \mathrm{kg}$, urea $1 \%$ dan molases sebanyak $5 \%$ dari pelepah sawit. Kemudian diaduk sampai rata, selanjutnya dimasukkan dalam kantong plastik, dipadatkan, diikat, dilakukan pemeraman selama 7 hari, dievaluasi kualitas fisiknya, dikeringkan dan digiling sampai berbentuk tepung.

\section{Fermentasi in vitro}

Fermentasi in vitro yang dilakukan berdasarkan metode Tilley \& Terry [12]. Tabung fermentor $100 \mathrm{ml}$ diisi $10 \mathrm{ml}$ cairan rumen, $40 \mathrm{ml}$ larutan McDougall, dan $500 \mathrm{mg}$ sampel perlakuan. Suhu shakerwater bath yang digunakan $39^{\circ} \mathrm{C}$. Inkubasi dilakukan selama 4 jam untuk pengambilan sampel bakteri, protozoa dan VFA parsial untuk perhitungan produksi gas metan. Perhitungan populasi protozoa, bakteri total, dan bakteri selulolitik menggunakan metode Ogimoto \& Imai [13]. Pengukuran produksi gas metan dengan pendekatan VFA parsial dari rumus Moss et al., [14] yaitu $\mathrm{CH}_{4}(\%)=0,45 \mathrm{C}_{2}-0,275 \mathrm{C}_{3}$ $+0,40 C_{4}$. Pengukuran produksi VFA parsial dilakukan dengan menggunakan Gas Chromatography dengan kolom kapiler tipe $10 \%$ SP-1200, $1 \% \mathrm{H}_{3} \mathrm{PO}_{4}$ dan gas nitrogen sebagai karier.

\section{Analisis statistik}

Penelitian menggunakan rancangan acak kelompok (RAK) dengan 4 perlakuan (pelepah sawit fermentasi dengan suplementasi tepung kulit jengkol pada level 0,2 , 4, dan 6\%) dengan 4 kelompok sebagai ulangan. Data yang diperoleh dianalisa secara statistik menggunakan ANOVA, perbedaan nyata antar perlakuan diuji lanjut dengan uji DMRT, Stell \& Torrie [15].

\section{HASIL}

Pada Tabel 1 disajikan data Kandungan gizi dan saponin pelepah sawit fermentasi, kulit jengkol, dan ransum in vitro.

\section{Profil mikroba rumen}

Pada Tabel 2 disajikan data profil mikroba rumen dengan suplementasi tepung kulit jengkol pada pelepah sawit fermentasi. Suplementasi kulit jengkol sebanyak 6\% dari pakan basal meningkatkan $(\mathrm{P}<0,05)$ populasi bakteri total dan bakteri selulotik. Bakteri total meningkat sebesar 22,25\% dan bakteri selulolitik sebesar $17,64 \%$ dari kontrol. Sedangkan suplementasikulit jengkol sebanyak 4 dan $6 \%$ menurunkan $(\mathrm{P}<0,05)$ populasi protozoa sebanyak $13,06 \%$ dan $30,86 \%$ dibandingkan dengan kontrol.

\section{Produksi gas metan, proporsi VFA parsial dan rasio $\mathrm{A} / \mathrm{P}$}

Pada Tabel 3 disajikan data produksi gas metan, proporsi VFA parsial, dan rasio $\mathrm{A} / \mathrm{P}$ dengan suplementasi tepung kulit jengkol 
Tabel 1. Kandungan gizi dan saponin pelepah sawit fermentasi, kulit jengkol dan ransum in vitro $(100 \% \mathrm{BK})$

\begin{tabular}{lcccccc}
\hline \multicolumn{1}{r}{ Bahan } & Abu & LK & PK & SK & BETN & Saponin \\
\hline PSF & 7,29 & 2,38 & 5,55 & 32,99 & 51,79 & 9,03 \\
KJ & 3,52 & 0,60 & 9,01 & 26,91 & 59,96 & 23,36 \\
PSF + 0\% KJ & 7,29 & 2,38 & 5,55 & 32,99 & 51,79 & 9,03 \\
PSF + 2\% KJ & 7,36 & 2,39 & 5,73 & 33,53 & 52,99 & 10,01 \\
PSF + 4\% KJ & 7,43 & 2,40 & 5,91 & 34,07 & 54,19 & 10,15 \\
PSF + 6\% KJ & 7,50 & 2,41 & 6,09 & 34,61 & 55,39 & 10,30 \\
\hline
\end{tabular}

Keterangan : PSF $=$ Pelepah Sawit Fermentasi, $\mathrm{KJ}=$ Kulit Jengkol. Analisa kandungan gizi di PAU, IPB University, Bogor (2019). Analisa saponin di Balitnak, Ciawi, Bogor (2019)

pada pelepah sawit fermentasi. Suplementasi kulit jengkol 2-6\% menurunkan $(\mathrm{P}<0,05)$ produksi gas metan sebesar 9,54-26,89\% dibandingkan dengan kontrol. Penurunan gas metan terbesar terjadi pada suplementasi kulit jengkol $2 \%$ yaitu sebesar 26,89\%. Suplementasi kulit jengkol sebanyak $2 \%$ dari pakan basal menurunkan $(\mathrm{P}<0,05)$ proporsi asetat dan rasio asetat/propionate $(\mathrm{A} / \mathrm{P})$ serta meningkatkan $(\mathrm{P}<0,05)$ proporsi propionat dibandingkan dengan perlakuan lain. Proporsi asetat dan rasio $\mathrm{A} / \mathrm{P}$ menurun sebesar $8,90 \%$ dan rasio A/P sebesar 33,54\%, sedangkan proporsi propionat meningkat sebesar 26,61\% dari kontrol. Proporsi asetat, propionat, dan rasio $\mathrm{A} / \mathrm{P}$ sama dengan kontrol bahkan meningkat $(\mathrm{P}<0,05)$ dengan suplementasi kulit jengkol sebanyak 4 dan $6 \%$. Suplementasi kulit jengkol sebanyak 6\% menurunkan $(P<0,05)$ proporsi butirat.

\section{PEMBAHASAN}

Peningkatan populasi bakteri total dan selulolitik serta penurunan protozoa dengan suplementasi kulit jengkol diduga karena kandungan saponin dari kulit jengkol mampu mensimulasi pertumbuhan bakteri dan penurunan populasi protozoa. Hart et al. [6] melaporkan bahwa saponin mampu membunuh atau melisiskan protozoa dengan membentuk ikatan yang kompleks dengan sterol yang terdapat pada permukaan membran protozoa sehingga mengganggu perkembangan protozoa yang menyebabkan membran pecah, sel lisis dan protozoa mati. Penghambatan protozoa akan menstimulasi pertumbuahn pakteri karena protozoa merupakan predator bakteri, Wallace [16].

Patra et al. [17] menyatakan bahwa penambahan saponin mampu menstimulasi secara langsung pertumbuhan bakteri $F$. succinogenes, $R$. flavefaciens dan genus Prevotella, yang mana bakteri tersebut bebas dari efek antiprotozoa. Penambahan Yucca pada dosis tinggi $(0,6 \mathrm{~g} / \mathrm{L}$ cairan rumen) dan Quillaja pada dosis rendah $(0,2 \mathrm{~g} / \mathrm{L}$ cairan rumen) berkontribusi terhadap peningkatan populasi bakteri selulolitik seperti $R$. flavefaciens dan F. succinogenes yang mampu meningkatkan efisiensi pakan. Hasil yang sama dilaporkan oleh Patra and Yu [18], bahwa penambahan saponin Quillaja pada dosis $0-6 \mathrm{~g} / \mathrm{L}$ cairan rumen) secara in vitro menurunkan populasi protozoa dan meningkatkan populasi bakteri $S$. ruminantium, $R$. amylophilus, $P$. ruminicola, and P. bryantii.

Suplementasi kulit jengkol sebanyak $2 \%$ mampu meningkatkan kadar saponin namun

Tabel 2. Profil mikroba rumen dengan suplementasi tepung kulit jengkol pada pelepah sawit fermentasi

\begin{tabular}{cccc}
\hline Perlakuan & $\begin{array}{c}\text { Populasi Bakteri Total } \\
\left(10^{9}\right)\end{array}$ & $\begin{array}{c}\text { Populasi Bakteri } \\
\text { Selulolitik }\left(10^{7}\right)\end{array}$ & $\begin{array}{c}\text { Populasi Protozoa } \\
\left(10^{5}\right)\end{array}$ \\
\hline $0 \%$ & $3,46^{\mathrm{a}} \pm 1,76$ & $8,73^{\mathrm{b}} \pm 0,74$ & $3,37^{\mathrm{c}} \pm 0,26$ \\
$2 \%$ & $3,46^{\mathrm{a}} \pm 1,76$ & $6,27^{\mathrm{a}} \pm 1,48$ & $3,33^{\mathrm{c}} \pm 0,24$ \\
$4 \%$ & $3,89^{\mathrm{a}} \pm 2,01$ & $7,73^{\mathrm{b}} \pm 1,75$ & $2,93^{\mathrm{b}} \pm 0,21$ \\
$6 \%$ & $4,45^{\mathrm{b}} \pm 2,34$ & $10,60^{\mathrm{c}} \pm 2,01$ & $2,33^{\mathrm{a}} \pm 0,09$ \\
\hline
\end{tabular}

Keterangan: Superskrip berbeda pada kolom yang sama menunjukkan berbeda nyata $(\mathrm{P}<0,05)$ 
Tabel 3. Produksi gas metan, proporsi VFA parsial, dan rasio A/P dengan suplementasi tepung kulit jengkol pada pelepah sawit fermentasi

\begin{tabular}{cccccc}
\hline Perlakuan & Gas Metan (\%) & Asetat (\%) & Propionat (\%) & Butirat (\%) & A/P \\
\hline $0 \%$ & $8,07^{\mathrm{c}} \pm 1,05$ & $62,33^{\mathrm{b}} \pm 2.84$ & $19,97^{\mathrm{a}} \pm 2,12$ & $17,70^{\mathrm{b}} \pm 0,99$ & $3,16^{\mathrm{b}} \pm 0,45$ \\
$2 \%$ & $5,91^{\mathrm{a}} \pm 0,84$ & $56,78^{\mathrm{a}} \pm 2.72$ & $27,23^{\mathrm{b}} \pm 1,90$ & $15,99^{\mathrm{b}} \pm 1,05$ & $2,10^{\mathrm{a}} \pm 0,24$ \\
$4 \%$ & $7,30^{\mathrm{b}} \pm 1,19$ & $65,44^{\mathrm{b}} \pm 2,23$ & $18,70^{\mathrm{a}} \pm 1,65$ & $15,86^{\mathrm{b}} \pm 1,96$ & $3,52^{\mathrm{c}} \pm 0,36$ \\
$6 \%$ & $7,01^{\mathrm{b}} \pm 1,32$ & $66,56^{\mathrm{c}} \pm 4,35$ & $19,90^{\mathrm{a}} \pm 4,79$ & $13,54^{\mathrm{a}} \pm 0,63$ & $3,04^{\mathrm{b}} \pm 0,47$ \\
\hline
\end{tabular}

Keterangan: Superskrip berbeda pada kolom yang sama menunjukkan berbeda nyata $(\mathrm{P}<0,05)$

tidak diikuti dengan peningkatan serat kasar yang tinggi, sehingga tidak berkontribusi pada peningkatan produksi gas metan. Guo et al. [19] melaporkan bahwa saponin menghambat gen metilkoenzim $\mathrm{M}$ reductase (mcrA) yang mengambil peran dalam tahap akhir metanogenesis. Selain itu penurunan produksi gas metan berhubungan dengan penurunan populasi protozoa rumen, $\mathrm{Hu}$ et al. [20]. Menurut Hess et al. [21], pada kenyataannya protozoa menyediakan ion $\mathrm{H}+$ untuk archae metanogen yang berhubungan dengan ektosimbiosis dan endosimbiosis. Hal ini diprediksi bahwa penurunan protozoa akan diikuti oleh menurunkan produksi gas metan.

Suplementasi kulit soapberry fruitmangosteen sampai $4 \%$ BK pakan yang mengandung $12 \%$ tannin dan $15 \%$ saponin menurunkan $(\mathrm{P}<0.01)$ produksi metan dengan perhitungan tidak langsung, yaitu menggunakan pendekaatn produksi VFA, Poungchompu et al. [22]. Hasil yang sama juga dilaporkan oleh Anantasook et al. [23] bahwa suplementasi senyawa bioaktif dari Terminalia chebula Retz $(8,4 \%$ tanin terkondensasi dan 9,9\% saponin) pada dosis $12 \mathrm{mg}$ secara in vitro menurunkan produksi metan sampai $60.9 \%$. Jadhav et al. [24] melaporkan bahwa suplementasi biji teh $(0,8 ; \quad 0,9$ dan $1,0 \%$ dari konsentrat $)$ menurunkan populasi protozoa $(54,6 ; 57,2$; dan $60,6 \%)$ dan produksi gas metan $(29,0 ; 33 ; 0$ dan $36,0 \%$ ) secara berurutan pada rasio hijauan dan konsentrat yang berbeda (rendah, medium dan tinggi hijauan)

Kulit jengkol mengandung serat kasar sebesar $26,91 \%$ dan menurut hasil penelitian Hidayah et al. [5] kandungan ligninnya sebesar $15,48-17,85 \%$. Chaves et al. [10] menyatakan bahwa kualitas pakan berpengaruh terhadap produksi gas metan
$\left(\mathrm{CH}_{4}\right)$ pada kajian in vitro dimana rendahnya konsentrasi karbohidrat yang tidak berserat pada legume dan hijauan berkontribusi terhadap tingginya produksi gas metan per gram bahan kering yang dikonsumsi. Produksi gas metan lebih tinggi 25\% pada pakan kualitas rendah, hal ini dikarenakan pada pakan kualitas tinggi rendah serat sehingga hasil fermentasi digunakan dalam pembentukan propionat. Jadhav et al. [25] menyatakan bahwa penurunan kecernaan secara in vitro mempengaruhi terjadinya penurunan produksi gas metan. Hasil yang sama ditemukan dari penelitian ini yaitu kecernaan bahan kering (KCBK) dan organiknya (KCBO) menurun dengan suplementasi kulit jengkol 2-6\%. KCBK dari penelitian ini $47,38 \%$ vs $42,49-43,90 \%$ dan KCBOnya yaitu $46,47 \%$ vs $41,66-42,59 \%$, Nurhaita et al. [26]

Penurunan proporsi asetat dan rasio $\mathrm{A} / \mathrm{P}$ serta peningkatan proporsi propinat terjadi pada suplementasi tepung kulit jengkol sebanyak $2 \%$, namun sebaliknya ketika ditambahkan 4-6\%. Hal ini diduga dikarenakan pada level $2 \%$ kulit jengkol mampu meningkatkan kadar saponin namun tidak diikuti dengan peningkatan serat kasar yang tinggi. Semakin banyak penambahan kulit jengkol (4-6\%) berkontribusi terhadap peningkatan kandungan serat kasar sehingga proporsi asetat dan rasio $\mathrm{A} / \mathrm{P}$ meningkat dan menurunkan proporsi propionat.

Kara et al. [27] menyatakan bahwa saponin berperan terhadap metabolik hidrogen $\left(\mathrm{H}_{2}\right)$ dari pembentukan gasmetan bergeser digunakan untuk membentuk propionat.Hidrogen merupakan produk fermentasi dari protozoa, fungi, dan beberapa bakteri.Archae metanogen hidup dengan mengkonsumsi $\mathrm{H}_{2}$ di dalam rumen dan berkompetisi dengan pembentukan propionat 
oleh bakteri penghasil propionat, Zinder [28]. Moss et al. [14] menyatakan bahwa dalam pembentukan propionat juga membutuhkan $\mathrm{H}_{2}$ sehingga akan berkompetisi dengan produksi gasmetan, sementarapembentukan asetat akan menghasilkan $\mathrm{H}_{2}$ yang merupakan subtrat archae metanogen untuk membentuk gasmetan dengan mereduksi $\mathrm{H}_{2}$ dan $\mathrm{CO}_{2}$ di dalam rumen. Sehingga dengan peningkatan produksi propionat akan menurunkan produksi asetat dan gasmetan.

Hasil penelitian Feng et al. [29] yang menggunakan saponin dari Tribulus terretris in vitro menunjukkan bahwa penambahan 0,6$0,9 \mathrm{~g} / \mathrm{L}$ cairan rumen menurunkan proporsi asetat $(64,69-64,92 \%)$ dan rasio $\mathrm{A} / \mathrm{P}(2,59-2,64)$ serta meningkatkan proporsi propionat (24,65-25,00\%) dibandingkan dengan kontrol $(66,19 \%$, 2,93, dan 22,57\%). Hasil yang sama ditunjukkan oleh penelitian Anantasook et al. [23], konsentrasi propionat meningkat $4.1 \%$ pada dosis $12 \mathrm{mg} / \mathrm{g}$ pakan dengan suplementasi Terminalia chebula yang mengandung saponin. Beauchemin et al. [2] melaporkan bahwa penurunan secara linier pada asetat dan rasio $\mathrm{A} / \mathrm{P}$ ketika disupementasi Schinopsis quebracho-colorado sebanyak 10 dan $20 \mathrm{~g} / \mathrm{kg}$ BK

Penambahan kulit jengkol (4-6\%) berkontribusi terhadap peningkatan kandungan serat kasar yang menyebabkan proporsi asetat dan rasio $\mathrm{A} / \mathrm{P}$ meningkat dan menurunkan proporsi propionat. Luthfi et al. [30] melaporkan bahwa kandungan serat yang rendah pada pakan berkorelasi positif terhadap rasio $\mathrm{A} / \mathrm{P}(\mathrm{r}=0,35, \mathrm{P}=0,09)$. Pakan dengan serat kasar tinggi akan menghasilkan $\mathrm{A} / \mathrm{P}$ rasio yang tinggi juga. Terjadi peningkatan rasio A/P sebesar 0,039 setiap kenaikan $1 \%$ dari serat kasar.

\section{KESIMPULAN}

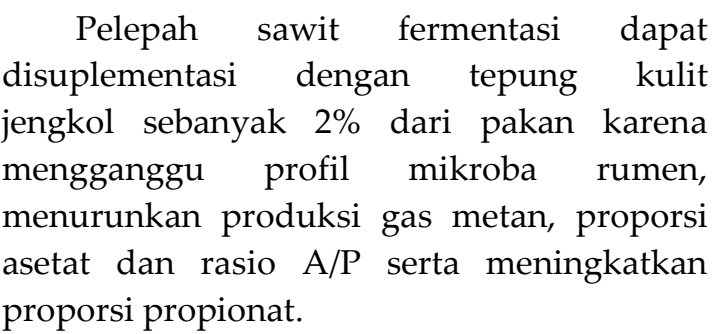

\section{KONFLIK KEPENTINGAN}

Kami menyatakan tidak ada konflik kepentingan yang berhubungan dengan keuangan, pribadi, atau lainnya dengan orang atau organisasi lain yang terkait dengan materi yang dibahas dalam naskah.

\section{UCAPAN TERIMA KASIH}

Tim penulis mengucapkan terimakasih kepada Direktorat Jenderal Pendidikan Tinggi, Kementrian Riset, Teknologi dan Pendidikan Tinggi Republik Indonesia yang sudah mendanai penelitian ini melalui hibah penelitian terapan tahun 2019 dengan kontrak nomor : 491/ LPPMUMB/2019 tanggal 10 Juli 2019.

\section{REFERENSI}

1. Khiaosa-ard, R. and Q. Zebeli. 2013. Metaanalysis of the effects of essential oils and their bioactive compounds on rumen fermentation characteristics and feed efficiency in ruminants. J. Anim. Sci. 91:1819-1830. Doi: 10.2527/jas.2012-5691

2. Beauchemin, K.A. and McGinn. 2006. Methane emissions from beef cattle: effects of fumaric acid, essential oil, and canola oil. J. Anim. Sci. 84:1489- 1496. Doi.org/ 10.2527/2006.8461489x

3. ayanegara, A. 2008. Reducing methane emissions from livestock: nutritional approaches. Proceedings of Indonesian Students Scientific Meeting (ISSM), Institute for Science and Technology Studies (ISTECS) European Chapter, 13-15 May 2008, Delft, the Netherlands: 18-21

4. Klevenhusen, F., A. Muro-Reyes, R. Khiaosa-ard, B. U. Metzler-Zebeli, and Q. Zebeli. 2012. A meta-analysis of effects of chemical composition of incubated diet and bioactive compounds on in vitro ruminal fermentation. Anim. Feed Sci. Technol. 176:61-69. Doi.org/10.1016/ j.anifeedsci.2012.07.008

5. Hidayah, N., R. Lubis, K.G. Wiryawan, and S. Suharti. 2019. Phenotypic identification, nutrients content, bioactive compounds of two jengkol (Archidendron jiringa) 
varieties from Bengkulu, Indonesia and their potentials as ruminant feed. Biodiv. 20:1671-1680. Doi.org/10.13057/biodiv/d20 0624

6. Hart K. J., D. R. Ya nez-Ruiz, S.M. Duval, N.R. McEwan, and C.J. Newbold. 2008. Plant extracts to manipulate rumen fermentation. Anim. Feed Sci. Technol. 147:8-35. Doi.org/10.1016/j.anifeedsci.2007 .09 .007

7. Soliva, C. R., S. L. Amelchanka, S. M. Duval, and M. Kreuzer. 2011. Ruminal methane inhibition potential of various pure compounds in comparison with garlic oil as determined with a rumen simulation technique (Rusitec). British J. of Nutr. 106:114-122. Doi: 10.1017/S000711451000 5684

8. Nurhaita, Ruswendi, Wismalinda, R., dan Robiyanto. 2014. Pemanfaatan pelepah sawit sebagai sumber hijauan dalam ransum sapi potong. J. Past. 4:38-41. Doi.org/10.24843/Pastura.2014.v04.i01.p09

9. Nurhayu, A., A. B. L. Ishak, dan A. Ella. 2014. Pelepah dan daun sawit sebagai pakan substitusi hijauan pada pakan ternak sapi potong di kabupaten luwu timur sulawesi selatan. Balai Pengkajian Teknologi Pertanian Sulawesi Selatan. Makasar

10. Chaves, A. V., L. C. Thompson, A. D. Iwaasa, S. L. Scott, M. E. Olson, C. Benchaar, D. M. Veira, and T. A. McAllister. 2006. Effect of pasture type (alfalfa vs. grass) on methane and carbon dioxide production by yearling beef heifers. Can. J. of Anim. Sci. 86:409-418. Doi.org/10.4141/A05-081

11. Astuti, T., M. N. Rofiq, dan Nurhaita. 2017. Evaluasi kandungan bahan kering, bahan organik dan protein kasar pelepah sawit fermentasi dengan penambahan sumber karbohidrat. J. Peter. 14:42-47

12. Tilley, J.M.A. and R.A. Terry. 1963. A twostage technique for the in vitro digestion of forage crops. J. of the Brit. Grasslan Soc. 18:104-111. Doi.org/10.1111/j.1365-2494.19 63.tb00335.x

13. Ogimoto, K. and S. Imai . 1981. Atlas of rumen microbiology. Japan Scientific Societes. Tokyo
14. Moss, A.R., J.P. Jouany, and J. Newbold. 2000. Methane production by ruminants: its contribution to global warming. Annal. Zootech. 49:231-253. hal.archives-ouvertes. fr/hal-00889894/

15. Stell, R. G. and J. H. Torrie. 1991. Prinsip dan prosedur statistik, suatu pendekatan biometrik. edisi 2. alih bahasa B. Sumantri. PT. Gramedia Pustaka Utama. Jakarta

16. Wallace, R.J. 2004. Antimicrobial properties of plant secondary metabolites. Proceeding of the Nutrition Society 63:621629.

17. Patra, A.K., J. Stiverson, and Z.Yu. 2012. Effects of quillaja and yucca saponins on communities and select populations of rumen bacteria and archaea, and fermentation in vitro. J. of Appl. Microbiol. 113:1329-1340. Doi: 10.1111/j.1365-2672.201 2.05440.x.

18. Patra, A.K. and Z. Yu. 2013. Effects of vanillin, quillaja saponin, and essential oils on in vitro fermentation and proteindegrading microorganisms of the rumen. Appl. Microbiol. Biotech. 1-9. Doi: 10.1007 /s00253-013-4930-x

19. Guo, Y.Q., J.X. Liu, Y. Lu, W.Y. Zhu, S.E. Denman, and C.S. McSweeney. 2008. Effect of tea saponin on methanogenesis, microbial community structure and expression of mcrA gene, in cultures of rumen micro-organisms. Lett. in Appl. Microbiol. 47:421-426. Doi: 10.1111/j.1472765X.2008.02459.x.

20. Hu,W.L,J.X. Liu, J.A. Ye,Y.M. Wu, and Y.Q. Guo. 2005. Effect of tea saponin on rumen fermentation in vitro. Anim. Feed Sci. Technol. 120:333-339. Doi: 10.1080/17450 390500353119.

21.Hess, H.D., M. Kreuzer, T.E. Diaz, C.E. Lascano, J.E. Carulla, C.R. Soliva, and A. Machmüller. 2003. Saponin rich tropical fruits affect fermentation and methanogensesis in faunated and defaunated rumen fluid. Anim. Feed Sci. and Technol. 109:79-94. Doi.org/10.1016/ S0377-8401(03)00212-8

22. Poungchompu, O., M. Wanapat, C. Wachirapakorn, S. Wanapat, and A. Cherthong. 2009. Manipulation of ruminal fermentation and methane production by 
dietary saponins and tannins from mangosteen peel and soapberry fruit. Archiv. of Anim. Nutr. 63:389-400. Doi: 10.1080/17450390903020406

23. Anantasook, N., M. Wanapat, P. Gunun, and A. Cherdthong. 2016. Reducing methane production by supplementation of Terminalia chebula RETZ. containing tannins and saponins. Anim. Sci. J. 87:783790. Doi: 10.1111/asj.12494.

24. Jadhav, R.V., A. Kannan, R. Bhar, O.P. Sharma, A. Gulati, K. Rajkumar, G. Mal, B. Singh, and M.R. Verma. 2018. Effect of tea (Camellia sinensis) seed saponins on in-vitro rumen fermentation, methane production and true digestibility at different forage to concentrate ratios. J. of Appl. Anim. Research. 46:118-124. Doi.org/10.1080/ 09712119.2016.1270823

25. Nurhaita, N. Definiati, dan N. Hidayah. 2020. Karakteristik fermentabilitas dalam rumen in vitro pada pelepah sawit fermentasi yang disuplementasi tepung kulit jengkol. J. Peter. 17:39-44. Doi.org/ 10.24014/jupet.v17i1.7710

26. Kara, K., B.K. Güçlü, and E. Baytok. 2015. Comparison of nutrient composition and anti-methanogenic properties of different Rosaceae species. J. Anim. Feed Sci. 24:30831. Doi.org/10.22358/jafs/65613/2015

27.Zinder, S.H. 1993. Physiological ecology of methanogens. In: J.G., Ferry (eds), methanogenesis: ecology, physiology, biochemistry \& genetics. Chapman \& Hall.Inc. New York

28. Feng, Zhi-Hua., Yu-Feng Cao, Yan-Xia Gao, Qiu-Feng. Li, and Jian-Guo Li. 2012. Effect of gross saponin of tribulus terrestris on ruminal fermentation and methane production in vitro. J. of Anim. and Vet. Adv. 11: 2121-2125

29. Beauchemin, K.A., S.M. McGinn, T.F. Martinez, and T.A. McAllister. 2007. Use of condensed tannin extract from quebracho trees to reduce methane emissions from cattle. J. Anim. Sci. 85:1990- 199. Doi: 10.2527/jas.2006-686

30. Luthfi, N., V. Restitrisnani, and M. Umar. 2018. The optimation of crude fiber content on fattening Madura bees cattle to achaive good A:P ratio and low methane production. IOP Conf. Series: Earth and Environmental Science 119: 1-5 